\title{
Constructed ponds colonised by crustacean zooplankton: local and regional influences
}

\author{
Chantal AUDET, ${ }^{1}$ Shannon MacPHEE, ${ }^{2}$ Wendel KELLER ${ }^{2 *}$ \\ ${ }^{1}$ Department of Biology, Laurentian University, 935 Ramsey lake Road, P3E 2C6 Sudbury; ${ }^{2}$ Cooperative Freshwater Ecology Unit, \\ Laurentian University, 935 Ramsey lake Road, P3E 2C6 Sudbury, Ontario, Canada \\ *Corresponding author: bkeller@laurentian.ca
}

\begin{abstract}
We examined monthly changes in crustacean zooplankton community composition during the initial colonisation period of a newly constructed pond (LWL pond), and in the littoral zone of an adjacent lake (Ramsey lake). In addition, four unconnected constructed ponds aged $\geq 20$ years with established zooplankton communities were sampled and compared to the LWL pond. The species richness of both LWL pond and Ramsey lake increased over the ice-free season, although Ramsey lake always had more species. Almost half of all species sampled occurred in both pond and lake. None of the zooplankton communities in the ponds used in the spatial analysis resembled communities of the LWL pond or one another. Taken together, these results indicate a lack of dispersal limitation, which suggests that differing local habitat factors had a strong influence in structuring the zooplankton communities.
\end{abstract}

Key words: zooplankton, colonisation, ponds, Ramsey lake, local, regional.

Received: October 2012. Accepted: April 2013.

\section{INTRODUCTION}

When a new habitat first forms, many factors will influence its potential for sustained species richness. Among these factors are the habitat's local characteristics, the biotic and abiotic conditions of the habitat itself that may facilitate or inhibit colonisation by new species, i.e. interactions with the local community through competition and predation, habitat size, etc. (De Meester et al., 2005). The characteristics of the region surrounding the habitat are also important in determining the structure of the developing community. Regional characteristics can influence formation of new communities by facilitating species dispersal to the new habitat through regional environmental conditions which influence access to the regional species pool (De Meester et al., 2005).

A meta-community refers to multiple local communities interconnected through dispersal of species between sites (Leibold and Norberg, 2004). Therefore, meta-community theory implies that the species richness of existing communities is influenced by interactions between both regional and local factors over time (Louette and De Meester, 2007; Allen et al., 2011). Also, the strength of the local or regional influence on a community may be subject to change over time (Allen et al., 2011). It has been shown that species have an easier time colonising areas with low local biodiversity, such as new ponds (Shurin, 2000). Therefore, it is assumed that regional characteristics are more important during earlier stages of succession, whereas the importance of local factors will increase with time due to dispersed species having increasing interactions with established local communities (Louette and De Meester, 2005, 2007). The regular dispersal required to maintain meta-communities is possible because many species of zooplankton have high dispersal rates (Louette and De Meester, 2005; Scheffer and Van Geest, 2006), otherwise known as dispersal capacity, which is the quantity of propagule transport to new habitats (Louette and De Meester, 2005).

Effective dispersal not only implies arriving at a new site, but also surviving the local conditions and successfully reproducing once there (Keller and Yan, 1998; Shurin, 2000; Louette and De Meester, 2005; Louette et al., 2008). In addition, the structure of an entire zooplankton community can be dependent on the order in which the species of the pioneer community arrived, known as priority effects (Frisch and Green, 2007; Louette and De Meester, 2007; Louette et al., 2008; Allen et al., 2011). Predators weaken competition between species, thus weakening the potential of priority effects and increasing the influence of species sorting (Louette and De Meester, 2007).

In the current study, we aimed to compare the influence of local vs regional factors and the role of time on the colonisation and biodiversity of crustacean zooplankton communities in new habitats. The objective was carried out through temporal and spatial sampling of crustacean zooplankton and habitat parameters in constructed ponds. The temporal study compared the crus- 
tacean zooplankton community of a newly constructed pond outside the Living with Lakes Center on the Laurentian University campus in Sudbury, Ontario (LWL pond) with the crustacean zooplankton community inhabiting the littoral zone of adjacent Ramsey lake, and assessed the pattern of succession in the new habitat as well as the similarity of the new habitat to an established nearby community. The spatial study compared the crustacean zooplankton community of the LWL pond to communities of several constructed ponds aged 20-30 years in the Greater Sudbury region and assessed whether local factors could explain the degree of similarity or dissimilarity between the ponds.

\section{METHODS}

In total, six separate sites (Fig. 1) were sampled for crustacean zooplankton and multiple habitat characteristics. The sites included a new pond ( $<1$ year), the shore- line area of an adjacent lake, and four unconnected, constructed ponds with differing local environments, all of which were $\geq 20$ years of age.

\section{Site descriptions}

LWL pond: this pond was $\sim 0.1$ ha in surface area and $<2 \mathrm{~m}$ in depth. It is adjacent to Ramsey lake and is connected to the lake by a culvert. However, flow was never observed through the culvert. The construction of the pond finished less than a year before sampling began. Terrestrial restoration efforts took place, with angiosperms planted around the pond.

Ramsey lake shoreline: This area encompasses the portion of Ramsey lake directly adjacent to the LWL pond. The culvert that connects with the pond is in this part of the lake. The area is only $\sim 1 \mathrm{~m}$ in depth and has soft sediment. The section sampled is surrounded by various aquatic macrophytes.

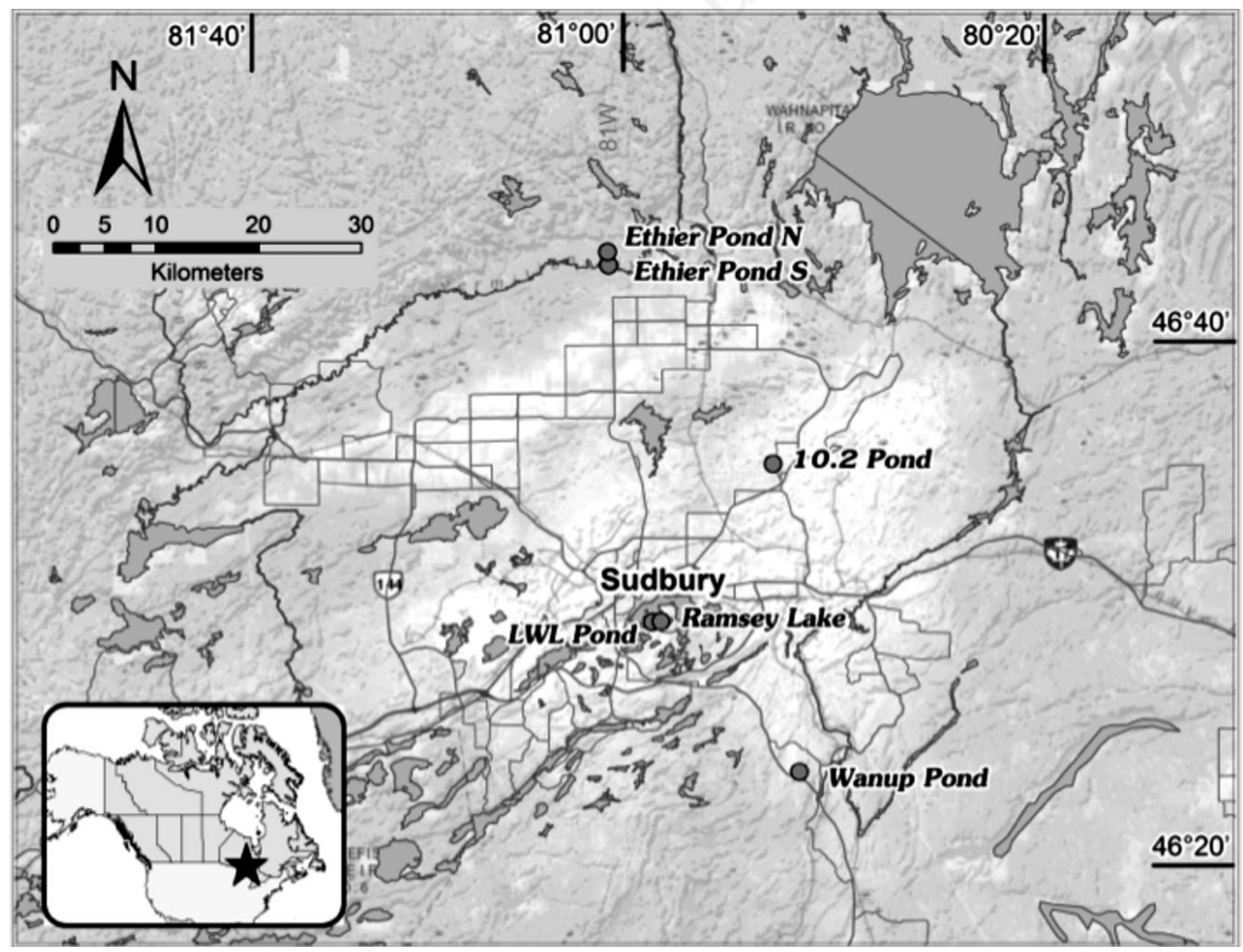

Fig. 1. Map of the study area showing locations of the study sites. 
10.2 pond: the pond is an old mining property owned by Vale (Vale Ltd., Toronto, Canada) located in the Garson area of Greater Sudbury. The site was a part of a large restoration project executed in the 1990s on a mined open pit. The pond has a surface area of 3.9 ha and a maximum depth of $\sim 13.5 \mathrm{~m}$. Various species of fish such as creek chub (Semotilus atromaculatus), common shiner (Notropis cornutus) redbelly dace (Chrosomus eos) and other minnows were introduced into the pond in 1997 and over the years many trees have been planted around the pond (Watson et al., 1999).

North Éthier pond: the pond is an old gravel quarry owned by Éthier Sand and Gravel Ltd. in the Val Thérèse area of Greater Sudbury. It was created in 1991-1992 and has a surface area of 0.2 ha and a maximum depth of 2.5 m. Rainbow trout (Oncorhynchus mykiss) and minnows have been introduced to the pond. The shoreline has had minor restoration with the planting of shrubs and trees.

South Ethier pond: this pond was created in the late 1970 s and is located on the same property as the North Éthier pond. The pond has a surface area of 0.1 ha. It is filled with algae and soft sediment. Many cattails and other macrophytes are established along the shoreline. No fish species were observed.

Wanup pond: the pond is an old gravel quarry area owned by Éthier Sand and Gravel Ltd. located by Old Wanup Road (Ontario Road 537). The pond was created in 1991-1992. It has a surface area of 3.6 ha and a maximum depth of $\sim 7 \mathrm{~m}$. The water is very clear and aqua coloured. No active restoration took place; however, there are some trees in the area. No fish species were observed.

\section{Sampling methods}

Sampling of the LWL pond took place monthly between $19^{\text {th }}$ April and $13^{\text {th }}$ September 2011. Ramsey lake was sampled monthly between $27^{\text {th }}$ May and $13^{\text {th }}$ September 2011. In June, July, August and September, the LWL pond and Ramsey lake were sampled on the same dates. Two separate samples of 10.2 pond were collected on $21^{\text {st }}$ July and $1^{\text {st }}$ September 2011. Wanup pond was sampled once on $27^{\text {th }}$ July 2011, whereas the North and South Éthier ponds were both sampled once on $6^{\text {th }}$ September 2011. All ponds, with the exception of 10.2 pond, were sampled using a conical plankton net $30 \mathrm{~cm}$ in diameter with $80 \mu \mathrm{m}$ mesh. 10.2 pond was sampled using a 12.5 $\mathrm{cm}$ diameter, $80 \mu \mathrm{m}$ mesh tow net. Horizontal transects were used to sample the shallow LWL pond, North Éthier pond, South Éthier pond and Ramsey lake, whereas the deeper Wanup pond and 10.2 pond were sampled vertically from $1 \mathrm{~m}$ off the bottom to the surface. All of the crustacean zooplankton samples were preserved in a $14 \%$ sugared and buffered formalin solution.

Water chemistry samples (Tab. 1) were collected and shipped to the Dorset Environmental Science Center to be processed by the Ontario Ministry of the Environment.

\section{Counting methods}

Species were identified through a Leica MZ16 stereomicroscope (Leica Microsystems GmbH, Wetzlar, Germany). Samples were fractioned using a Folsom plankton splitter and sub-samples were counted until a total of approximately 240 individuals were processed. The remain-

Tab. 1. Spatial study pond water chemistry.

\begin{tabular}{|c|c|c|c|c|c|}
\hline Parameter & LWL pond & North Éthier pond & South Éthier pond & 10.2 pond & Wanup pond \\
\hline Alkalinity $\left(\mathrm{mg} \mathrm{L}^{-1}\right)$ & 133.0 & 35.1 & 27.3 & 102.9 & 32.4 \\
\hline $\mathrm{Al}\left(\mathrm{mg} \mathrm{L}^{-1}\right)$ & 0.13 & 0.005 & 0.050 & 0.006 & 0.036 \\
\hline $\mathrm{Ca}\left(\mathrm{mg} \mathrm{L}^{-1}\right)$ & 59.4 & 10.3 & 7.9 & 24.2 & 46.4 \\
\hline $\mathrm{DOC}\left(\mathrm{mg} \mathrm{L}^{-1}\right)$ & 16.6 & 2.2 & 3.4 & 4.75 & 3.2 \\
\hline Chloride $\left(\mathrm{mg} \mathrm{L}^{-1}\right)$ & 141.0 & 10.0 & 8.16 & 1.77 & $\mathrm{~N} / \mathrm{A}$ \\
\hline Colour (true colour units) & 23.2 & 4.4 & 8.4 & 8.27 & 6.00 \\
\hline Conductivity $\left(\mu \mathrm{s} \mathrm{cm}^{-1}\right)$ & N/A & 134.0 & 111.0 & 233.8 & 724.0 \\
\hline $\mathrm{Cu}\left(\mathrm{mg} \mathrm{L}^{-1}\right)$ & 0.007 & 0.001 & 0.001 & 0.002 & 0.002 \\
\hline $\mathrm{Fe}\left(\mathrm{mg} \mathrm{L}^{-1}\right)$ & 0.130 & 0.030 & 0.250 & 0.015 & 0.040 \\
\hline $\operatorname{Mg}\left(\mathrm{mg} \mathrm{L}^{-1}\right)$ & 21.6 & 4.14 & 3.27 & 10.9 & 12.3 \\
\hline $\mathrm{Ni}\left(\mathrm{mg} \mathrm{L}^{-1}\right)$ & 0.013 & $<0.001$ & 0.001 & 0.005 & 0.003 \\
\hline $\mathrm{N}\left(\mathrm{NH}_{3}+\mathrm{NH}_{4}\right)\left(\mathrm{mg} \mathrm{L}^{-1}\right)$ & 0.028 & 0.022 & 0.014 & 0.027 & $<0.004$ \\
\hline $\mathrm{N}\left(\mathrm{NO}_{2}+\mathrm{NO}_{3}\right)\left(\mathrm{mg} \mathrm{L}^{-1}\right)$ & $<0.002$ & $<0.002$ & $<0.002$ & $<0.002$ & 0.394 \\
\hline $\mathrm{TKN}\left(\mathrm{mg} \mathrm{L}^{-1}\right)$ & 0.510 & 0.198 & 0.213 & 0.408 & 0.195 \\
\hline $\mathrm{pH}$ & 8.37 & 7.47 & 7.19 & 8.17 & 7.51 \\
\hline $\mathrm{K}\left(\mathrm{mg} \mathrm{L}^{-1}\right)$ & 12.1 & 1.77 & 1.6 & 1.01 & 6.06 \\
\hline Sulphate $\left(\mathrm{mg} \mathrm{L}^{-1}\right)$ & 67.1 & 12.6 & 8.6 & 16.6 & 4.1 \\
\hline $\mathrm{Na}\left(\mathrm{mg} \mathrm{L}^{-1}\right)$ & 234.0 & 8.06 & 7.13 & 2.43 & 68.5 \\
\hline
\end{tabular}

Al, aluminum; Ca, calcium; DOC, dissolved organic carbon; N/A, not available; CU, copper; Fe, iron; Mg, magnesium; Ni, nickel; N, nitrogen; TKN, total Kjeldahl nitrogen; $P$, phosphorus; $K$, potassium; Na, sodium. 
ing fractions were then scanned for rare species. If Chaoborus were found in any samples it was noted; however, individuals present were not assigned to a specific species or life stage.

Certain species were combined into complexes due to the difficulty of distinguishing individuals into separate species. Daphnia pulex, Daphnia catawba and Daphnia pulicaria were combined into the Daphnia pulex complex. Scapholeberis kingi and Scapholeberis aurita were combined to form Scapholeberis spp. Bosmina freyi and Bosmina liederi were referred to as Bosmina spp. and Eubosmina longspina and Eubosmina (Neobosmina) tubicen were referred to as Eubosmina spp. Any Alona species found was simply referred to as Alona spp.

\section{RESULTS}

\section{Temporal study}

The species richness in both LWL pond and Ramsey lake increased during the ice-free season (Fig. 2), although Ramsey lake always had more species. In total, 18 species were found in the LWL pond, while 24 species were found in the littoral zone of Ramsey lake. Thirteen species were present in both water bodies (Tab. 2). Five species collected in the LWL pond were not found in Ramsey lake: Paracyclops poppei, Leptodiaptomus sicilis, Onychodiaptomus birgei, Eucyclops agilis and Leptodiaptomus ashlandi. Eleven species were found in Ramsey lake but not in the LWL pond: Diaphanosoma birgei, Acroperus harpae, Camptocercus rectirostris, Diacyclops nanus, Eurycerus lamellatus, Sida crystallina, Pleuroxus sp., Latona setifera, Simocephalus serrulatus, Microcyclops sp. and Ilyocryptus spinifer.

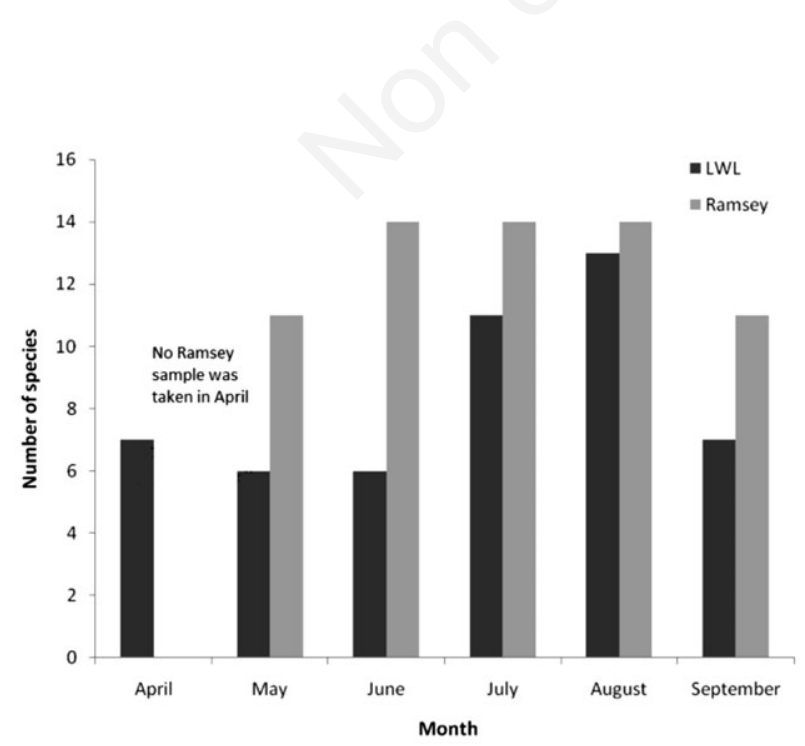

Fig. 2. Species richness of the LWL pond vs species richness of the adjacent Ramsey lake area on a monthly basis in 2011 (summer).
The zooplankton dynamics in the LWL pond were driven mainly by Daphnia. The Daphnia pulex complex accounted for almost $77 \%$ of the overall zooplankton abundance in the LWL pond. Furthermore, Daphnia mendotae made up almost $9 \%$ of the abundance. In contrast to the LWL pond, juvenile copepods made up almost $80 \%$ of the crustacean zooplankton community in Ramsey lake. Bosmina and Eubosmina species each made up an additional $8 \%$ of the abundance.

\section{Spatial study}

The relative abundances of the species found on a single date in the different ponds sampled during the summer of 2011 are shown in Tab. 3. In the LWL pond, 7 species were found and the D. pulex complex made up $60 \%$ of the abundance. Calanoid nauplii made up $25 \%$ of the abundance and cyclopoid nauplii $13 \%$. Only 3 species were found in the North Éthier pond. Calanoid nauplii and

Tab. 2. Mean relative abundance of species found in LWL pond and Ramsey lake between May and September 2011.

\begin{tabular}{|c|c|c|}
\hline Species & LWL pond $(\%)$ & Ramsey lake (\%) \\
\hline Daphnia pulex complex & 76.9 & $<1$ \\
\hline Cyclopoid copepodid & 8.9 & 34.2 \\
\hline Calanoid nauplii & 2.6 & 33.0 \\
\hline Cyclopoid nauplii & 1.5 & 9.8 \\
\hline Daphnia mendotae & 8.7 & $<1$ \\
\hline Eubosmina spp. & $<1$ & 8.4 \\
\hline Bosmina spp. & $<1$ & 8.0 \\
\hline Polyphemus pediculus & $<1$ & 2.7 \\
\hline Calanoid copepodid & $<1$ & 2.3 \\
\hline Scapholeberis spp. & 1.4 & $<1$ \\
\hline Leptodiaptomus minutus & $<1$ & $<1$ \\
\hline Chydorus sphaericus & $<1$ & $<1$ \\
\hline Diacyclops bicuspidatus thomasi & $<1$ & $<1$ \\
\hline Acroperus harpae & 0 & $<1$ \\
\hline Onychodiaptomus birgei & $<1$ & 0 \\
\hline Alona spp. & $<1$ & $<1$ \\
\hline Acanthocyclops vernalis complex & $<1$ & $<1$ \\
\hline Mesocyclops edax & $<1$ & $<1$ \\
\hline Diaphanosoma birgei & 0 & $<1$ \\
\hline Sida crystallina & 0 & $<1$ \\
\hline Skistodiaptomus oregonensis & $<1$ & $<1$ \\
\hline Camptocercus rectirostris & 0 & $<1$ \\
\hline Eurycercus lamellatus & 0 & $<1$ \\
\hline Diacyclops nanus & 0 & $<1$ \\
\hline Ilyocryptus spinifer & 0 & $<1$ \\
\hline Latona setifera & 0 & $<1$ \\
\hline Microcyclops sp. & 0 & $<1$ \\
\hline Pleuroxus sp. & 0 & $<1$ \\
\hline Simocephalus serrulatus & 0 & $<1$ \\
\hline Leptodiaptomus sicilis & $<1$ & 0 \\
\hline Eucyclops agilis & $<1$ & 0 \\
\hline Leptodiaptomus ashlandi & $<1$ & 0 \\
\hline Paracyclops poppei & $0^{*}$ & 0 \\
\hline Mean seasonal abundance $\left(\mathrm{n} / \mathrm{m}^{3}\right)$ & $50,609.60$ & 7420.85 \\
\hline
\end{tabular}


copepodids comprised $79 \%$ of the abundance. Cyclopoid nauplii made up $14 \%$ and Bosmina spp. $6 \%$ of the abundance. Thirteen species were found in the South Éthier pond. Juvenile cyclopoids comprised $70 \%$ of the abundance, while juvenile calanoids made up 7.5\% and $C h y$ dorus sphaericus comprised $17 \%$ of the abundance. Seven species were found in 10.2 pond. Calanoids comprised $58 \%$ of the abundance while juvenile cyclopoids made up $22 \%$. Bosmina spp. made up almost $7 \%$ and Eubosmina spp. almost $9 \%$ of the abundance. The Wanup pond contained 8 species. Bosmina spp. made up $66 \%$ of the abundance, while Eubosmina spp. comprised 25\%. Juvenile cyclopoids made up $7 \%$ of the abundance and juvenile calanoids just over $1 \%$.

\section{DISCUSSION}

\section{Temporal study}

Ramsey lake had higher species richness than the LWL pond. The fact that 13 of the 18 species found in the LWL pond during the summer were also found in Ramsey lake suggests that high zooplankton dispersal exists between the lake and the pond. However, the fact that there were an ad- ditional 11 species sampled in Ramsey lake that were not found in the pond, that 5 species in the pond were not found in the lake, along with the disproportional relative species abundances suggests that local factors are having a stronger influence than regional factors in shaping the community. This is logical, because dispersal limitation is rarely a factor when a large source of colonisers is in close proximity (Shurin, 2000). Because dispersal rates are typically higher in the case of short range dispersal compared to long range dispersal, environmental factors and interspecific competition are usually dominant in controlling community development through species sorting (Shurin, 2000; Louette and De Meester, 2005, 2007; Kurek et al., 2011).

The fact that five species of crustacean zooplankton were found in the LWL pond and that were not found in Ramsey lake suggests that either they were present in such low abundance in Ramsey lake that they were missed during the sampling or that they came from other water bodies. Wind and rain have been suggested as common passive transportation mechanisms for crustacean zooplankton dispersal (Cáceres and Soluk, 2002); therefore, it is reasonable that the species might have come from other nearby lakes or ponds. Waterfowl and insects have

Tab. 3. Relative abundance of species in the ponds sampled during summer 2011. For ponds that were sampled multiple times in summer, the end of the season sample was used (September 13 for the LWL pond and September 1 for the 10.2 pond).

\begin{tabular}{|c|c|c|c|c|c|}
\hline Species & LWL pond $(\%)$ & North Éthier pond (\%) & South Éthier pond (\%) & 10.2 pond $(\%)$ & Wanup pond $(\%)$ \\
\hline Calanoid nauplii & 24.6 & 75.4 & 7.3 & 45.6 & 1.1 \\
\hline Bosmina spp. & $<1$ & 6.2 & & 6.8 & 66.1 \\
\hline Cyclopoid nauplii & 13.1 & 13.9 & 23.9 & 17.1 & 6.6 \\
\hline Daphnia pulex complex & 59.9 & & $<1$ & & \\
\hline Cyclopoid copepodid & $<1$ & & 46.2 & 4.8 & 0.23 \\
\hline Eubosmina spp. & & & & 8.5 & $<1$ \\
\hline Chydorus sphaericus & $<1$ & & 17.3 & 1.1 & \\
\hline Calanoid copepodid & 1.3 & 4.1 & $<1$ & 12.5 & $<1$ \\
\hline Leptodiaptomus siciloides & & $<1$ & & 3.1 & \\
\hline Alona spp. & $<1$ & & 1.5 & & \\
\hline Harpacticoida sp. & & & $<1$ & & \\
\hline Ilyocryptus spinifer & & & $<1$ & & \\
\hline Onychodiaptomus birgei & $<1$ & & & & \\
\hline Skistodiaptomus oregonensis & & & & $<1$ & \\
\hline Simocephalus vetulus & & & $<1$ & & $<1$ \\
\hline Tropocyclops extensus & & & $<1$ & & $<1$ \\
\hline \multicolumn{6}{|l|}{ Acanthocyclops } \\
\hline vernalis complex & & & $<1$ & & \\
\hline Ectocyclops phaleratus & & & $<1$ & & \\
\hline Mesocyclops edax & $<1$ & & & & $<1$ \\
\hline Pleuroxus sp. & & & $<1$ & & \\
\hline Chydorus faviformis & & & 1.4 & & \\
\hline Diaphanosoma birgei & & & $<1$ & & $<1$ \\
\hline Ophryoxus gracilis & & & $<1$ & & \\
\hline Orthocyclops modestus & & & & & $<1$ \\
\hline Leptodiaptomus ashlandi & $<1$ & & & & \\
\hline Total abundance $\left(\mathrm{n} / \mathrm{m}^{3}\right)$ & $21,018.56$ & 862.98 & 2447.49 & $20,704.89$ & 7156.87 \\
\hline Species richness & 7 & 3 & 13 & 7 & 8 \\
\hline
\end{tabular}

Immature calanoids and cyclopoids were not included in richness counts unless no adults were found. 
also been suggested as dispersal methods for zooplankton (Frisch and Green, 2007).

Interestingly, the five species found in the LWL pond and that were not found in Ramsey lake were all copepods ( 3 calanoids and 2 cyclopoids). It is not uncommon for copepods to be among the first colonisers of new habitats. Cyclopoids are thought to be good spatial dispersers (Cáceres and Soluk, 2002) and frequently colonise new habitats (Yan et al., 2004). Although copepods reproduce sexually, female cyclopoids are able to store sperm making mating multiple times unnecessary, therefore it is plausible that a new habitat can be colonised by one fertilised female (Frisch and Green, 2007). O. birgei was found in August in the LWL pond and had developed a stable population size by September. The species has not been previously found in any of the sampled Sudbury regional lakes (W. Keller, unpublished data).

On the other hand, of the 11 species found in Ramsey lake that were not found in the LWL pond, 10 were cladocerans. As with most crustacean zooplankton, cladocerans also have a high capacity for dispersal (Louette and De Meester, 2005; Kurek et al., 2011). However, priority effects can have a large influence in forming the communities of new habitats (Allen et al., 2011). D. pulex complex and $D$. mendotae were among the first species to be found in the pond, and were able to rapidly reproduce, reaching densities that were much higher than other species by May. This, along with the fact that all the cladoceran species found in Ramsey lake that were not found in the LWL pond had low relative abundances, indicates that it is possible that they were unable to successfully colonise the LWL pond due to competition with the established Daphnia spp. even if they were well suited for the pond's abiotic conditions (Louette et al., 2008).

The LWL pond also had a higher abundance of Chaoborus spp. than the lake by the end of the season, and Chaoborus spp. have been reported to prey on Bosmina spp. (Keller and Yan, 1998). The fact that Bosmina spp. are smaller in size would have also made them more accessible as prey than larger Daphnia spp. In a previous study, it was found that Bosmina longirostris was unable to colonise a new pond, most likely due to competition with an established species Daphnia obtusa and heavy predation by Chaoborus (Louette et al., 2008).

\section{Spatial study}

While single sampling dates do not account for seasonal species succession, samples collected in mid to late summer should reflect conditions when most species would be expected to be present in northern Ontario lakes. Single sample surveys, as used herein, have frequently been shown to be very useful in describing zooplankton community changes along environmental gradients (Keller and Pitblado, 1984; Keller and Conlon, 1994).
The species richness of the ponds in the spatial studies varied widely. Although the North and South Éthier ponds were physically only meters apart, they showed the highest difference in species richness of all the ponds sampled. This suggests that local habitat characteristics are responsible for the species richness and community composition of these two ponds as opposed to dispersal limitations. Most of the species richness of the South Éthier pond was made up of Chydorids. One of the probable reasons why C. sphaericus and other Chydorid species were more successful in the nutrient rich (Tab. 1) South Éthier pond than in the other ponds is because they are typically found in shallow waters (Keller and Yan, 1998) with eutrophic conditions (Hofmann, 2001) and aquatic macrophytes. The North Éthier pond was very low in phosphorus and oligotrophic, therefore species which are typically found in eutrophic conditions or that require high levels of phosphorus would not have been well suited for the pond.

10.2 pond had a total crustacean zooplankton abundance that was almost as high as that of the LWL pond and similar species richness. However, the abundance was due to a high number of juvenile copepods rather than Daphnia. Daphnia pulicaria was previously one of the dominant species in 10.2 pond (Watson, Hunt and Keller, 1999); however, as previously mentioned, no Daphnia spp. were found in 10.2 pond on either of our sample dates. Since the earlier samplings, multiple species of fish have been stocked in 10.2 pond (Watson, Hunt and Keller, 1999), and fish can be associated with a decrease in Daphnia spp. populations (Keller and Yan, 1998; Steiner, 2004).

Wanup pond's low zooplankton abundance and species richness are most likely due to its extremely low level of nutrients. It had a total phosphorous value of $3.0 \mu \mathrm{g} \mathrm{L}^{-1}$ (Tab. 1) which is below the Ontario provincial water quality objectives (MOEE, 1994), and is considered indicative of ultra-oligotrophic conditions (CCME, 2004). The low nutrients likely led to low phytoplankton abundance. In turn, the limited phytoplankton food source would likely lead to low zooplankton abundance, including reduced calanoid and juvenile cyclopoid abundance (Soto and Hurlbert, 1991).

Although there is a size difference between the ponds, it is unlikely that size was an important factor in determining species richness or community composition between the sites because they only ranged from 0.1 to 3.9 ha, and in fact the largest ponds did not contain the highest species richness. There was substantial variation in pond chemistry (Tab. 1); however, the role of chemistry as a potential factor influencing zooplankton communities is not clear. As indicated earlier, nutrient concentrations are likely affecting some zooplankton assemblages through effects on phytoplankton food sources. Chemical toxicity does not appear to be of concern in these ponds since they are all above neutral $\mathrm{pH}$ with high alkalinity. Metal concentrations approached or were below suggested safe lev- 
els (MOEE, 1994) and metals would not be expected to be particularly toxic in waters of such high ionic strength. The effects, if any, of high concentrations of $\mathrm{Na}$, and $\mathrm{Cl}$ due to road salting are not known; however, species richness was not particularly low in the LWL pond which had the highest concentrations of these ions.

\section{CONCLUSIONS}

In conclusion, the results from the temporal study indicate that there was high dispersal to the LWL pond. The 13 species the pond had in common with Ramsey lake suggest that the lake is a large colonisation source; however, the fact that 5 species were found in the LWL pond that were not found in Ramsey lake along with the large differences in species abundances suggests that local factors played a stronger role in the community formation than did broad regional factors. The fact that none of the ponds from the spatial study resembled the LWL pond or each other suggests that in the long-term, local factors such as habitat structure, availability of nutrients, predation and competition have also been more influential than regional factors in shaping the community compositions of the four other constructed ponds.

These conclusions fit well with the meta-community theory that local factors increase their influence on community composition with a growing local species pool (Louette and De Meester, 2005, 2007). Because the spatial ponds have all had between 20 and 30 years of colonisation time, their species pool is assumed to be maximised and the fact that the two ponds with the greatest and lowest species richness were very close to each other, suggests that they are not dispersal limited; therefore, local factors likely had a stronger role. Although the LWL pond is relatively new, the fact that there is a large potential colonisation source directly adjacent to the pond would suggest that the local species pool would increase more quickly than in more isolated conditions. Therefore, the influence of local factors potentially manifested itself earlier in the LWL pond than in the majority of new habitats.

\section{ACKNOWLEDGMENTS}

We thank Lynne Witty for assistance with zooplankton taxonomy, Jocelyne Heneberry for providing water chemistry analyses, and Chantal Sarrazin-Delay for map production.

\section{REFERENCES}

Allen MR, VanDyke JN, Cáceres CE, 2011. Metacommunity assembly and sorting in newly formed lake communities. Ecology 92:269-275.

Cáceres CE, Soluk DA, 2002. Blowing in the wind: a field test of overland dispersal and colonization by aquatic invertebrates. Oecologia 131:402-408.
CCME, 2004. Canadian water quality guidelines for the protection of aquatic life. Phosphorus: Canadian guidance framework for the management of freshwater systems. Canadian Council of Ministers of the Environment, Winnipeg: 6 pp.

De Meester L, Declerck S, Stoks R, Louette G, Van De Meutter F, De Bie T, Michels E, Brendonck L, 2005. Ponds and pools as model systems in conservation biology, ecology and evolutionary biology. Aquat. Conserv. 15:715-725.

Frisch D, Green AJ, 2007. Copepods come first: rapid colonization of new temporary ponds. Fund. Appl. Limnol. 168:289-297.

Hofmann W, 2001. Late-Glacial/Holocene succession of the chironomid and cladoceran fauna of the Soppensee (Central Switzerland). J. Paleolimnol. 25:411-420.

Keller W, Conlon M, 1994. Crustacean zooplankton communities and lake morphometry in Precambrian Shield lakes. Can. J. Fish. Aquat. Sci. 51:2424-2434.

Keller W, Pitblado, JR, 1984. Crustacean plankton in northeastern Ontario lakes subjected to acidic deposition. Water Air Soil Poll. 23:271-291.

Keller W, Yan ND, 1998. Biological recovery from lake acidification: zooplankton communities as a model of patterns and processes. Restor. Ecol. 6:364-375.

Kurek J, Weeber RC, Smol JP, 2011. Environment trumps predation and spatial factors in structuring cladoceran communities from Boreal Shield lakes. Can. J. Fish. Aquat. Sci. 68:1408-1419.

Leibold MA, Norberg J, 2004. Biodiversity in metacommunities: plankton as complex adaptive systems? Limnol. Oceanogr. 49:1278-1289.

Louette G, De Meester L, 2005. High dispersal capacity of cladoceran zooplankton in newly founded communities. Ecology 86:353-359.

Louette G, De Meester L, 2007. Predation and priority effects in experimental zooplankton communities. Oikos 116:419-426.

Louette G, De Meester L, Declerk S, 2008. Assembly of zooplankton communities in newly created ponds. Freshwater Biol. 53:2309-2320.

MOEE, 1994. Policies, guidelines and provincial water quality objectives. Ministry of the Environment and Energy of Ontario ed., Toronto: $32 \mathrm{pp}$.

Scheffer M, Van Geest GJ, 2006. Small habitat size and isolation can promote species richness: second-order effects on biodiversity in shallow lakes and ponds. Oikos 112:227-231.

Shurin JB, 2000. Dispersal limitation, invasion resistance and the structure of pond zooplankton communities. Ecology 81:3074-3086.

Soto D, Hurlbert SH, 1991. Log-term experiments on calanoidcyclopoid interactions. Ecol. Monogr. 61:245-265.

Steiner CF, 2004. Daphnia dominance and zooplankton community structure in fishless ponds. J. Plankton Res. 26:799-810.

Watson G, Hunt C, Keller B, 1999. Natural and enhanced aquatic ecosystem development at Inco's former Garson 10.2 open pit mine, p. 419-428. In: Proc. Mining and the Environment II. Laurentian University ed. Available from: http://pdf.library.laurentian.ca/medb/conf/Sudbury99/Ecosy stems/EHERT4.PDF

Yan ND, Girard R, Heneberry JH, Keller W, Gunn JM, Dillon PJ, 2004. Recovery of copepod, but not cladoceran, zooplankton from severe and chronic effects of multiple stressors. Ecol. Lett. 7:452-460. 